APP-113 Comparative Transduction Efficiencies of AAV2 vs. Lentivirus for Cancer and Vascular Endothelial Cells

USC, Metic Transplantation Laboratory", Institute for Genetic Medicine, University of Southern California'

Kazuo Mizutani", Ataru Sazawa"

Applications for gene therapy with adeno-associated virus (AAV) and lentivirus vectors will be limited to tissues efficiently transduced by the vector based on tropism. To allow precise quantitation of titer and transduction efficiency, FACS analysis was used to detect gene transfer and expression of the GFP marker. The relative transduction efficiencies were tested on target cell types, including Hela, NMU breast cancer cells, 5637 and J82 bladder cancer cells. Furthermore, as gene transfer to endothelium may be important for cancer gene therapy, we also tested transduction of BAEC, HMVEC-L, and HUVEC. Standard transduction titers on Hela cells were $10^{7} \sim 10^{8} \mathrm{TU} / \mathrm{ml}$ for lentivirus and $109 \mathrm{TU} / \mathrm{ml}$ for AAV. In cancer cells, AAV vectors were more efficient for gene transfer to 5637 and $\mathrm{J}$ 82 cells, but less efficient for NMU and T24 cells. and endothelial cells in vitro. In contrast, lentivirus vectors showed high transduction efficiency for cancer cells, and variable efficiency for endothelial cell transduction which appeared to be inversely correlated with passage number in culture.

\section{APP-114 腎盉尿管腫鸼の深達度診断}

\section{産業医科大学 医学部 泌尿器科学}

西井 久枝, 佐藤 英樹, 山田 陽司, 藤本 直浩, 高橋 康一 松本 哲朗

1992 年から 2002 年までの 10 年間、当科にて精查・加療行った 腎盖尿管腫瘍患者、男性 48 名、女性 10 名、計 58 名を対象に、 初診時主訴、術前細胞診、初診時から診断までの期間、診断方法、 病理学的診断について検討した。診断時年龆は平均 68.7 藏 (44 歳から 86 歳)。初診時主訴は症候性肉眼的血尿 6 名このうち腹 痛が 4 名・全身倦意感が 1 名・排尿時痛が 1 名、無症侯性肉眼 的血尿 27 名であり、肉眼的血尿を主訴としたものは合計 33 名 であった。腹痛、险落痛などの疼痛を主訴としたものがが 8 名、 食欲不振、全身倦急感などその他が 3 名、14名で自觉的主訴は なかったがこのうち影微鏡的血尿が 6 名、超音波検査で水腎症 が指摘されたものが 6 名、自然尿細胞診がClass5 を指摘された ものが 2 名であった。初診時から腎孟腫瘍診断時までの平均期 間は 5.0 力月であり 37 名が 1 力月以内に診断されていた。尿䋥 胞診は自然尿、尿管尿で術前、術後に探取されており、西像診断 方法は排泄性腎盉造影、逆行性腎盉造影、造影 CTであった。街 前診断と病理診断がなされたいたのは計 28 名であったが、画像 診断で understaging されていたものは 6 名、overstaging され たものは11名、一致したものは11名であった。 overstaging 症例は Ta、T1 症例であったが、病理診断で一致・understaging 症例と比皎すると尿細胞唁のClass が低い僧向にあった。

\section{APP-115湭腃癌影断における尿中カルレティ キュリンの有用性の检捨}

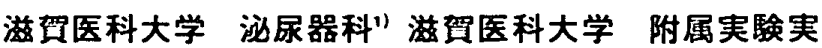 習機器センター2) 倉敖中央病院 泌尿器科”) 東北大学 医学部 泌尿器科 4}

影山進",吉草 達宽", 磪野 高敬 ${ }^{2}$, 岩城 秀出洙" 吉村 耕治 ${ }^{3}$, 寺井 章人 ${ }^{31}$, 荒井 陽一“侗田 裕作 ${ }^{11}$

【目的】われわれは昨年の会で、膀胱癌 (BT) のプロテオーム解析で得 た診断マーカー候補タンパク質 10 種を発表した。今回、これらのうちの 一つである calreticulin (CRT) について診断マーカーとしての有用性を 検討した。(方法り膀胱組緎での検討では腫易 22 検体、正常上皮 10 検体を 対象として、抗CRT 抗体による Western blot (WB) でCRT 発現を確認 しバンド强度を定量した。定量化には HeLa 細胞 lysate l $\mu$ g 由来のCRT バンドを基準（=lunit）とした。尿を用いた検討ではBT 患者尿 27 検体 および非 BT 患者からなる対照尿 131 検体を対象として、WBの免疫産 物の有無により定性的に評価した。結果]膀脂組織 lysate l $\mu \mathrm{g}$ 中のCRT 発現は正常部が $0.40 \pm 0.32$ unitに対し腫暘部が $1.02 \pm 0.39$ で有意に高 かった (Mann-Whitney U 検定、 $\mathrm{p}=0.0003)$ 。尿中にも WBでCRT の存 在が確認でき、BT 患者尿では 19/27検体（感度 70\%)で隄性であった。 しかし、非 BT 患者尿のうち尿路感染症 (UTI) 患者康でも高い陽性率を 示した $(7 / 8$ 検体、87\%)。対照群から UTI を除くと陽性反応は $22 / 123$ 検体 (18\%) に認められた（特異度 82\%)。(站詥】CRTはBT 組織で高発 現している上に尿中にも認められた。NMP22やBTA と比較しても遜色 ない感度・特異度を示し、診断マーカーとしての有用性が示唆された。一 方、UTIで高い偽陽性率を認めるという久点も明らかとなった。

\section{APP -116 CDDP 併用放射線潽法施行膀胱癌症例 における虽光 multiplex PCR 法による LOH 解析, apoptosis 関連因子の発現解 析と治療効果, 予後との関連について}

\section{山口大学 医学部 泌尿器科学}

松本 洋明,和田 尚,山本 義明,平田宽, 矢野 誠司 松田 健二, 大見 千英高, 鄭 泰秀, 吉弘 悟, 松山 豪泰 内藤 克輔

【目的】我々は局所漫婔性膀脱癌症例に対してCDDP 併用放射線療法を 施行し，LOH 解析を行うと共に免疫組織染色を用いて apoptosis 関連因 子の発現を検討し, 治療効果や予後の予測因子を検討した。(方法) CDDP 併用放射線痖法を施行した膀脂癌患者 62 例を对象とした。治療 前後の癌紐織のパラフィン連続切片より DNA を抽出し，アポトーシス 関連遗伝子の存在が報告されている 17p13と 1p36 領域のマイクロサテ ライトマーカーをもちいて multiplex PCRを行いLOH 解析を行った。 また，TUNEL 法により apoptosis index (AI) を算出し, Ki-67, p53, bcl2, bax の発現を免疫染色にて解析し，治療効果や予後との関連を検討し た。[結果】症例をCR 群と非CR 群に分けて検討したところ，AI，Ki-67. p53. bcl-2 および bax 単独では治療効果との相関はなかったが, bax/bcl2 比は，CR 群では非 CR 群に比べて有意に高值であった $(\mathrm{p}=0.0289)$ 。 予後は単変星解析では Ki-67の発現，p73の LOH の有無で有意差を認 めたが，多変疍解析では，p73のLOHの有無が有意な予後予測因子で

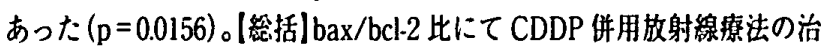
療効果を予測できる可能珄があり，また，治療効果によらず p73の LOH が重要な予後予測因子となる叮能住が示㖫された。 